\title{
Analisis Kesalahan Peserta Didik Kelas X SMK Dalam Menyelesaikan Soal Pemecahan Masalah Berdasarkan Tahapan Kastolan
}

\author{
Suci Aisyah Putri, Edwin Musdi \\ (C) 2021 JEMS (Jurnal Edukasi Matematika dan Sains) \\ This is an open access article under the CC-BY-SA license \\ (https:/ / creativecommons.org/licenses/by-sa/4.0/) ISSN 2337-9049 (print), ISSN 2502-4671 (online)
}

\begin{abstract}
Abstrak:
Matematika adalah salah satu mata pelajaran yang penting untuk meningkatkan kemampuan pemecahan masalah matematis peserta didik Sekolah Menengah Kejuruan (SMK). Akan tetapi, masih banyak yang melakukan kesalahan saat menyelesaikan soal pemecahan masalah. Tujuan artikel ini adalah untuk mendeskripsikan kesalahan peserta didik dalam menyelesaikan soal pemecahan masalah berdasarkan tahapan Kastolan. Jenis penelitian ini adalah penelitian deskriptif kualitatif. Teknik pengumpulan data dalam penelitian ini adalah tes tertulis dan catatan lapangan. Subjek penelitian adalah peserta didik kelas X SMK. Hasil penelitian ini menunjukkan bahwa ada 3 jenis kesalahan yang dilakukan peserta didik dalam menyelesaikan soal pemecahan masalah menurut tahapan Kastolan, yaitu (1) kesalahan konseptual, ada sebesar $42 \%$ peserta didik yang melakukan kesalahan ini; (2) kesalahan prosedural, sebesar $28 \%$ peserta didik yang melakukan kesalahan ini; dan (3) kesalahan teknik, ada sebesar 33\% peserta didik yang melakukan kesalahan.
\end{abstract}

Kata Kunci: Analisis Kesalahan, Kastolan, Pemecahan Masalah

\begin{abstract}
:
Mathematics is one of the important subjects to improve the mathematical problem solving ability of Vocational High School $(S M K)$ students. However, there are still many who make mistakes when solving problem solving problems. The purpose of this article is to describe student errors in solving problem solving problems based on the Kastolan stages. This type of research is descriptive qualitative research. Data collection techniques in this study were written tests and field notes. The research subjects were students of class X SMK. The results of this study indicate that there are 3 types of errors made by students in solving problem solving problems according to the Kastolan stages, namely (1) conceptual errors, there are $42 \%$ of students who make this error; (2) procedural errors, $28 \%$ of students made this mistake; and (3) technical errors, there are 33\% of students who make mistakes.
\end{abstract}

Keywords : Error Analysis, Kastolan, Problem Solving

\section{Pendahuluan}

Kemampuan pemecahan masalah sangat penting dimiliki oleh peserta didik terutama lulusan Sekolah Menengah Kejuruan (SMK). Lulusan dari SMK diharapkan bisa lebih terampil dan siap dalam dunia kerja, dan mampu memecahkan permasalahan yang ada di dunia kerja. Salah satu mata pelajaran yang dapat membantu peserta didik dalam memecahkan permasalahan dikehidupan sehari-hari adalah matematika. Hal ini serupa dengan yang dikatakan oleh (Adiastuty, 2015) bahwa matematika merupakan salah satu pembelajaran yang dapat membantu peserta didik meningkatkan kemampuan pemecahan masalahan sehingga dapat menyelesaikan permasalahan dunia kerja dengan baik.Pada kenyataannya, kemampuan pemecahan masalah matematis peserta didik masih tergolong rendah. Hal ini dapat dilihat pada hasil studi Programme for International Student Assessment (PISA) Indonesia tahun 2018. Skor peserta didik Indonesia mengalami penurunan dari tahun 
2015. Skor matematika Indonesia di PISA 2018 adalah 379 (rata-rata OECD 489), sedangkan pada tahun 2015 adalah 386 (rata-rata OECD 490).

Hasil ini menunjukkan bahwa kemampuan matematika peserta didik Indonesia masih jauh di bawah rat-rata (Tohir, 2019). Selain itu, hasil Trend in International Mathematics and Science Study (TIMSS) tahun 2015 menunjukkan kemampuan matematika peserta didikmasih di bawah rata-rata. Pasalnya, Indonesia berada diperingkat 44 dari 49 negara dengan skor 397 dari skor rata-rata internasional 500 (Hadi \& Novaliyosi, 2019). Salah satu penyebab rendahnya kemampuan matematis peserta didik ini adalah karena mereka masih kesulitan dalam memahami konsep maupun prosedur matematika sehingga mengalami kesalahan dalam proses pembelajaran.

Kesalahan-kesalahan yang dilakukan peserta didik dalam proses pembelajaran akan berpengaruh terhadap pemahaman konsep matematika peserta didik. Pasalnya, matematika merupakan ilmu yang sistematis sehingga jika konsep terdahulu terjadi kesalahan maka konsep berikutnya kemungkinan akan terjadi kesalahan juga. Hal ini sejalan dengan yang dikatakan (Imswatama \& Muhassanah, 2016), yaitu matematika adalah ilmu terstruktur yang saling berkaitan dengan konsep yang satu dengan konsep yang lainnya. Oleh sebab itu, kesalahan belajar ini perlu ditindaklanjuti sehingga kemampuan pemecahan masalah matematis peserta didik dapat berkembang dan tujuan pembelajaran matematika dapat tercapai.

Salah satu kesalahan peserta didik dalam proses belajar matematika adalah kesalahan dalam menyelesaikan soal-soal pemecahan masalah. Ada banyak metode yang dapat digunakan untuk mengidentifikasi kesalahan peserta didik dalam menyelesaiakan soal matematika. Salah satunya dengan menggunakan tahapan Kastolan. Tahapan Kastolan dibedakan keselahan peserta didik menjadi 3, yaitu kesalahan konseptual, kesalahan prosedural, dan kesalahan teknik (Raharti \& Yunianta, 2020). Adapun indikator kesalahan menurut tahapan Kastolan disajikan dalam Tabel 1 (Ulfa \& Kartini, 2021).

Tabel 1. Indikator Kesalahan Tahapan Kastolan

\begin{tabular}{|c|c|c|}
\hline No. & Jenis Kesalahan & Indikator Kesalahan \\
\hline 1. & Kesalahan Konseptual & $\begin{array}{l}\text { a. Peserta didik tidak dapat menafsirkan } \\
\text { menggunakan salah satu istilah, konsep, } \\
\text { atau prinsip. } \\
\text { b. Peserta didik tidak dapat memilih } \\
\text { rumus matematika yang harus } \\
\text { digunakan menyelesaikan soal dengan } \\
\text { benar. } \\
\text { c. Peserta didik sudah dapat memilih } \\
\text { rumus, tetapi tidak dapat menerapkan } \\
\text { rumus tersebut dengan benar. }\end{array}$ \\
\hline 2. & Kesalahan Prosedural & $\begin{array}{l}\text { a. Peserta didik tidak bisa menuliskan } \\
\text { langkah penyelesaian soal sesuai } \\
\text { perintah soal. } \\
\text { b. Peserta didik tidak dapat } \\
\text { menyelesaikan soal sampai bentuk } \\
\text { paling sederhana. }\end{array}$ \\
\hline 3. & Kesalahan Teknik & $\begin{array}{l}\text { a. Peserta didik melakukan kesalahan } \\
\text { dalam operasi hitung. } \\
\text { b. Peserta didik melakukan kesalahan }\end{array}$ \\
\hline
\end{tabular}




dalam memindahkan angka atau
operasi hitung dari langkah satu ke
langkah berikutnya.

Kesalahan belajar dalam matematika yang dilakukan peserta didik ada banyak faktor yang mempengaruhinya diantaranya tidak tahu konsep, miskonsepsi, ataupun ceroboh dalam mengerjakan soal. Peserta didik tidak tahu konsep maksudnya adalah mereka tidak memahami konsep yang dipelajari dengan baik. Maksud dari miskonsepsi adalah ketidaksesuaian konsep yang dimiliki peserta didik dengan konsep para ahli (Irawan et al., 2012). Dengan kesalahan-kesalahan yang dilakukan peserta didik ini akan berdampak pada kemampuan matematis terutama kemampuan pemecahan masalah. Untuk itu perlu adanya usaha-usaha untuk mengidentifikasi kesalahan yang dilakukan peserta didik dalam menyelesaikan soal pemecahan masalah sehingga mereka tidak akan melakukan kesalahan yang sama dan kemampuan pemecahan masalah mereka dapat meningkat. Oleh sebab itu, peneliti tertarik untuk mendeskripsikan kesalahan peserta didik dalam menyelesaikan soal pemecahan masalah berdasarkan tahapan Kastolan.

\section{Metode}

Jenis penelitian yang digunakan adalah penelitian deskriptif kualitatif. Penelitian kualitatif merupakan penelitian dengan metode untuk mengeksplorasi dan memahami makna yang berasal dari masalah sosial dengan cara pandang penelitian yang bergaya induktif (Widada, 2011). Penelitian deskriptif adalah penelitian untuk mengumpulkan informasi mengenai status suatu gejala yang ada yaitu gejala menurut apa adanya pada saat penelitian dilakukan.

Penelitian kualitatif yang dimaksud adalah untu memahami fenomena tentang apa yang dialami subjek penelitian dengan cara mendeskripsikan dalam bentuk kata-kata dan bahasa pada suatu konteks khusus yang alamiah dengan memanfaatkan berbagai metode alamiah (Moleong, 2018). Fenomena yang dimaksud dalam penelitian ini adalah kesalahan peserta didik dalam menyelesaikan soal pemecahan masalah berdasarkan tahapan Kastolan.

Penelitian ini bertujuan untuk menganalisis kesalahan peserta didik kelas X SMK dalam menyelesaikan soal pemecahan masalah berdasarkan tahapan Kastolan. Metode pengumpulan data dalam penelitian ini adalah dengan teknik triangulasi mengecek data kepada sumber yang sama dengan teknik yang berbeda (Sugiyono, 2015). Subjek penelitian ini adalah peserta didik kelas X Jurusan Pemasaran SMK Negeri 2 Padang sebanyak 36 oarang. Lokasi penelitian ini adalah di SMK Negeri 2 Padang provinsi Sumatera Barat.

Teknik pengumpulan data yang digunakan pada penelitian ini adalah dengan memberikan soal tes pemecahan masalah dan menggunakan teknik purposive sampling yaitu teknik penentuan sampel dengan pertimbangan tertentu tergantung kebutuhan penelitian yang dilakukan yang berfungsi untuk mendapatkan informasi yang maksimum, bukan untuk digeneralisasikan serta dibantu dengan catatan lapangan (Suharsimi;, 2013).

\section{Hasil Dan Pembahasan}

Dalam mengumpulkan data pada penelitian ini, peneliti menggunakan tes berupa soal pemecahan masalah dengan materi barisan dan deret aritmatika dan catatan lapangan. Berikut soal pemecahan masalah matematis yang diberikan kepada peserta didik. "Siswa kelas X Pemasaran memproduksi masker selama masa pandemic Covid-19. Kemudian, masker tersebut dijual di 2Mart SMKN 2 Padang. Hari pertama terjual sebanyak 30 masker, hari kedua terjual sebanyak 42 masker. Begitu juga pada hari-hari berikutnya selalu mengalami kenaikan 
penjualan yang sama. Bantulah siswa tersebut menaksirkan berapa jumlah masker yang sudah terjual di 2 Mart selama 7 hari." Berdasarkan hasil tes peserta didik dalam menyelesaikan soal pemecahan masalah matematis, diperoleh persentase jawaban peserta didik berdasarkan indikator pemecahan masalah yang terlihat pada Tabel 2.

Tabel 2. Persentase Jawaban Peserta didik pada Tes Pemecahan Masalah Kelas X Jurusan Pemasaran SMKN 2 Padang Tahun Pelajaran 2020/ 2021

\begin{tabular}{|c|c|c|c|c|c|}
\hline \multirow{2}{*}{ Indikator } & \multicolumn{5}{|c|}{ Skor } \\
\hline & 0 & 1 & 2 & 3 & 4 \\
\hline $\begin{array}{l}\text { Mengidentifikasi unsur-unsur yang } \\
\text { diketahui, yang ditanyakan, dan kecukupan } \\
\text { unsur yang diperlukan }\end{array}$ & $19 \%$ & $22 \%$ & $17 \%$ & $28 \%$ & $14 \%$ \\
\hline $\begin{array}{l}\text { Merumuskan masalah matematika atau } \\
\text { menyusun model matematika }\end{array}$ & $17 \%$ & $28 \%$ & $22 \%$ & $14 \%$ & $19 \%$ \\
\hline $\begin{array}{l}\text { Menerapkan strategi untuk menyelesaikan } \\
\text { berbagai masalah dalam atau di luar } \\
\text { matematika }\end{array}$ & $28 \%$ & $19 \%$ & $31 \%$ & $8 \%$ & $14 \%$ \\
\hline $\begin{array}{l}\text { Menjelaskan atau menginterprestasikan hasil } \\
\text { sesuai permasalahan asal }\end{array}$ & $19 \%$ & $25 \%$ & $28 \%$ & $14 \%$ & $14 \%$ \\
\hline
\end{tabular}

Berdasarkan Tabel 2 di atas, terlihat bahwa kemampuan pemecahan masalah peserta didik masih rendah. Hal ini terlihat dari persentase skor peserta didik setiap indikatornya yang memperoleh skor 4 masih sangat rendah dibandingkan persentase yang memperoleh skor 0, 1 ataupun skor 2. Persentase tersebut memperlihatkan bahwa peserta didik melakukan kesalahan-kesalahan dalam menyelesaikan soal pemecahan masalah sehingga berdampak pada kemampuan pemecahan masalah matematisnya. Oleh sebab itu, diperlukan analisis kesalahan peserta didik dalam menyelesaikan soal pemecahan masalah berdasarkan tahapan Kastolan.

Berikut ini dijabarkan kesalahan peserta didik dalam menyelesaikan soal pemecahan masalah berdasarkan tahapan Katolan.

1. Kesalahan Konseptual

Kesalahan konseptual terjadi ketika peserta didik tidak dapat menafsirkan menggunakan salah satu istilah, konsep, atau prinsip. Selain itu, kesalahan ini terjadi jika peserta didik tidak dapat memilih rumus matematika yang harus digunakan menyelesaikan soal dengan benar atau peserta didik sudah dapat memilih rumus, tetapi tidak dapat menerapkan rumus tersebut dengan benar. Berikut ini beberapa jawaban peserta didik yang memperlihatkan kesalahan konseptual.

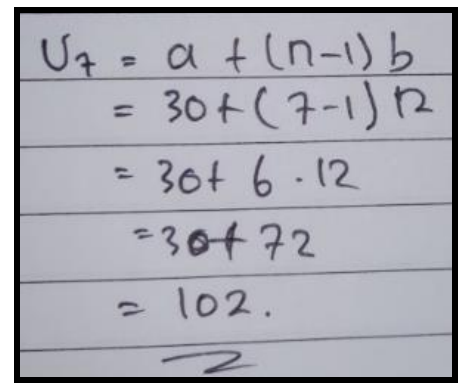

Gambar 1. Kesalahan Konseptual Peserta Didik A 


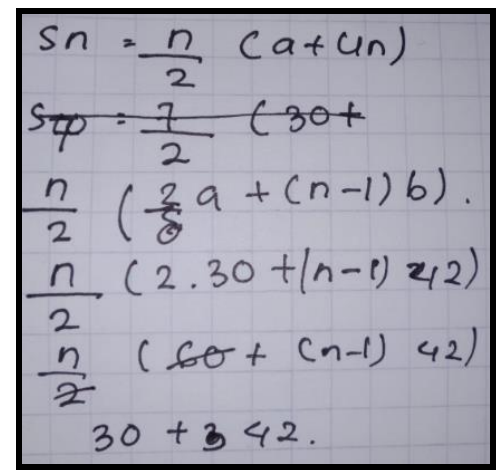

Gambar 2. Kesalahan Konseptual Peserta didik B

Pada Gambar 1 terlihat bahwa peserta didik belum mampu memilih rumus yang tepat untuk menyelesaikan soal pemecahan masalah tersebut. Peserta didik tidak memahami soal dengan baik sehingga melakukan kesalahan untuk menentukan jumlah $n$ suku pertama dari deret aritmatika yang terdapat dalam soal tersebut. Selain itu, peserta didik terlihat kebingungan dalam menerapkan rumus suku ke-n atau rumus jumlah $n$ suku pertama barisan dan deret aritmatika.

Pada Gambar 2 memperlihatkan kesalahan peserta didik dalam menerapkan rumus jumlah $\mathrm{n}$ suku pertama deret aritmatika. Peserta didik sudah benar dalam memilih rumus untuk menyelesaikan soal pemecahan masalah, tetapi melakukan kesalahan dalam menerapkan rumus tersebut. Terlihat bahwa peserta didik salah dalam menentukan beda suku barisan aritmatika dan belum bisa menentukan nilai dari $\mathrm{n}$ yang ada pada rumus tersebut.

2. Kesalahan Prosedural

Kesalahan yang kedua yaitu kesalahan procedural. Kesalah ini terjadi jika peserta didik tidak bisa menuliskan langkah penyelesaian soal sesuai perintah soal atau peserta didik tidak dapat menyelesaikan soal sampai bentuk paling sederhana. Berikut salah satu jawaban peserta didik yang melakukan kesalahan prosedural.

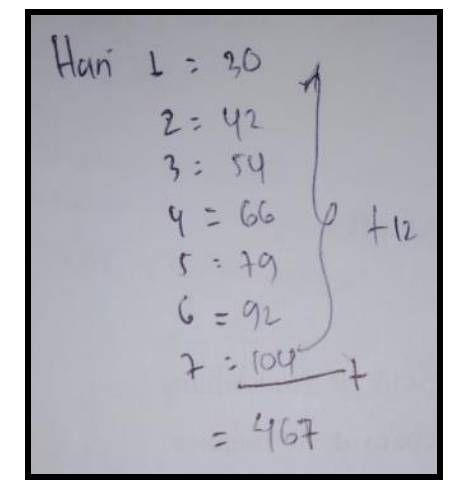

\section{Gambar 3. Kesalahan Prosedural Peserta Didik}

Gambar 3 di atas memperlihatkan kesalahan prosedural yang dilakukan peserta didik karena tidak bisa menuliskan langkah penyelesaian sesuai perintah soal. Peserta didik sudah memahami soal dengan sangat baik, tetapi dalam penyelesaikannya langkah yang digunakan belum tepat. seharusnya peserta didik menggunakan rumus jumlah $\mathrm{n}$ suku pertama deret aritmatika dalam menyelesaikan soal tersebut. 


\section{Kesalahan Teknik}

Kesalahan yang terakhir pada tahapan Kastolan adalah kesalahan teknik. Kesalahan ini dapat terjadi jika peserta didik melakukan kesalahan dalam operasi hitung ataupun peserta didik melakukan kesalahan dalam memindahkan angka atau operasi hitung dari langkah satu ke langkah berikutnya. Berikut beberapa jawaban peserta didik yang melakukan kesalahan teknik.

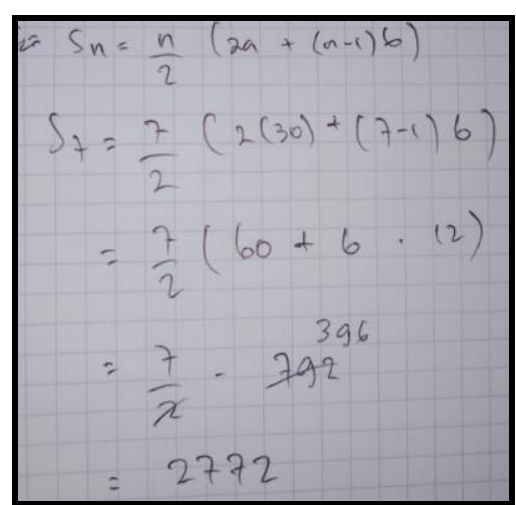

\section{Gambar 4. Kesalahan Teknik Peserta Didik C}

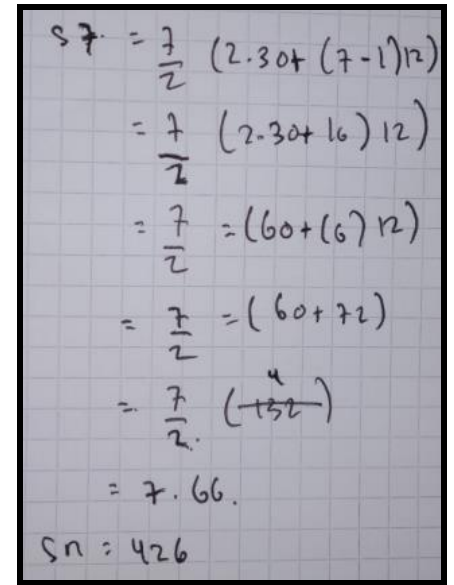

\section{Gambar 5. Kesalahan Teknik Peserta Didik D}

Pada Gambar 4 terlihat bahwa peserta didik melakukan kesalahan teknik disebabkan oleh kesalahan saat menggunakan operasi hitung. Kesalahan yang dilakukan peserta didik adalah saat menambahkan 60 dan 6 baru kemudian dikalikan dengan 12. Seharusnya peserta didik mengalikan 6 dan 12 kemudian menambahkan dengan 60, barulah bisa memperoleh hasil yang benar.

Pada Gambar 5 juga memperlihatkan kesalahan peserta didik dalam melakukan operasi hitung. Peserta didik salah dalam menghitung hasil akhir dari soal yang disajikan. Hasil akhir yang seharusnya adalah 462, sedangkan yang ditulis peserta didik adalah 426 .

Berdasarkan uraian di atas, terlihat bahwa peserta didik melakukan kesalahankesalahan dalam menyelesaikan soal pemecahan masalah sesuai tahapan Kastolan. Hal inilah yang menyebabkan nilai tes kemampuan pemecahan masalah peserta didik masih rendah. Berikut disajikan persentase kesalahan peserta didik berdasarkan tahapan Kastolan pada Tabel 3. 
Tabel 3. Persentase Kesalahan Peserta Didik Berdasarkan Tahapan Kastolan

\begin{tabular}{clc}
\hline No. & \multicolumn{1}{c}{ Jenis Kesalahan } & Persentase Kesalahan \\
\hline 1. & Kesalahan Konseptual & $42 \%$ \\
2. & Kesalahan Prosedural & $28 \%$ \\
3. & Kesalahan Teknik & $33 \%$ \\
\hline
\end{tabular}

Berdasarkan Tabel 3 di atas, terlihat bahwa kesalahan yang paling banyak dilakukan peserta didik adalah kesalahan konseptual yaitu sebanyak $42 \%$. Hal ini terjadi dikarenakan mereka masih belum paham dengan materi yang disajikan sehingga melakukan kesalahan dalam memilih ataupun menerapkan rumus suku ke-n dan rumus jumlah $n$ suku pertama barisan aritmatika.

\section{Simpulan}

Berdasarkan hasil pembahasan yang telah dipaparkan di atas, dapat disimpulkan bahwa kesalahan belajar peserta didik saat menyelesaikan soal pemecahan masalah berdasarkan tahapan Kastolan, yaitu kesalahan konseptual, kesalahan prosedural, dan kesalahan teknik. Pendidik diharapkan mampu menganalisis kesalahan-kesalahan peserta didik berdasarkan tahapan Kastolan sehingga dapat meminimalisir kesalahan disaat menyelesaikan soal pemecahan masalah. Dengan demikian, peserta didik dapat mengoptimalkan kemampuan pemecahan masalah matematisnya.

\section{Daftar Rujukan}

Adiastuty, N. (2015). Tahapan Pembelajaran Matematika SMK Yang Mengarah Pada Pemecahan Masalah (Polya). Euclid. https://doi.org/10.33603/e.v2i2.367

Hadi, S., \& Novaliyosi. (2019). TIMSS Indonesia (Trends in International Mathematics and Science Study). Prosiding Seminar Nasional \& Call For Papers Program Studi Magister Pendidikan Matematika Universitas Siliwangi, 562-569.

Imswatama, A., \& Muhassanah, N. (2016). Analisis Kesalahan Mahasiswa Dalam Menyelesaikan Soal Geometri Analitik Bidang Materi Garis Dan Lingkaran. Suska Journal of Mathematics Education. https://doi.org/10.24014/sjme.v2i1.1368

Irawan, E., Riyadi, R., \& Triyanto, T. (2012). Analisis Miskonsepsi Mahasiswa Stkip Pgri Pacitan Pada Mata Kuliah Pengantar Dasar Matematika Pokok Bahasan Logika Ditinjau Dari Gaya Kognitif Mahasiswa. Journal of Mathematics and Mathematics Education, 2(1). https://doi.org/10.20961/jmme.v2i1.9942

Moleong, L. J. (2018). Metodologi penelitian kualitatif / penulis, Prof. DR. Lexy J. Moleong, M.A. In PT Remaja Rosdakarya.

Raharti, A. D., \& Yunianta, T. N. H. (2020). Identifikasi Kesalahan Matematika Siswa Smp Berdasarkan Tahapan Kastolan. Journal of Honai Math, 3(1), 77-100. https://doi.org/10.30862/jhm.v3i1.114

Sugiyono. (2015). Metode Penelitian dan Pengembangan Pendekatan Kualitatif, Kuantitatif, dan R\&D. Metode Penelitian Dan Pengembangan Pendekatan Kualitatif, Kuantitatif, Dan 
$R \mathcal{E D}$.

Suharsimi;, A. (2013). Dasar-Dasar Evaluasi Pendidikan. In Jakarta: Bumi Aksara.

Tohir, M. (2019). Hasil PISA Indonesia Tahun 2018 Turun Dibanding Tahun 2015. December 2019, 10-12. https://doi.org/10.31219/osf.io/pcjvx

Ulfa, D., \& Kartini, K. (2021). Analisis Kesalahan Siswa dalam Menyelesaikan Soal Logaritma Menggunakan Tahapan Kesalahan Kastolan. Jurnal Cendekia: Jurnal Pendidikan Matematika, 5(1), 542-550. https://doi.org/10.31004/cendekia.v5i1.507

Widada, W. (2011). Penelitian Pendidikan Matematika. FKIP UNIB. 